\title{
Osmanlı Devleti'nde İlk Basın Yayın Faaliyetleri ve Tuna Gazetesi
}

\section{Osman İBRAHİMOV ${ }^{*}$}

\section{Öz}

Osmanlı İmparatorluğu'nda 1839 yılında Tanzimat Fermanı'nın ilân edilmesiyle her alanda olduğu gibi merkez ve taşra yönetiminde de yeni ve merkezî bir yapı kurmaya çalışılmıştır.

Osmanlı İmparatorluğu'nda ve dış siyasi, sosyal ve ekonomik gelişmelerin ortaya çıkardığı sorunların çözülebilmesi amacıyla 7 Kasım 1864 tarihinde önceden hazırlanan ve yapılan küçük değişikliklerle "Tuna Vilâyeti Nizamnamesi" Takvim-i Vekayi’de yayınlanarak, yürürlüğe girmiștir. Nizamnamenin dokuzuncu maddesinde her vilâyette bir matbaanın kurulması öngörülmüştür. Bu doğrultuda Tuna Vilâyeti'nde ilk vilâyet gazetesi yayınlanmışıır.

Osmanlı döneminde yayınlanan vilâyet gazeteleri, yayınlandıkları vilâyetlerin resmi gazetesi görevini yapmışlardır. Vilâyet gazeteleri, hem yönetim ile ilgili halka yapılan uygulamalarla ilgili halka bilgi vermişler hem de sosyal hayatın içinden haberler yayınlamışlardır. Bu doğrultuda Tuna Vilâyet Gazetesi, vilâyet dâhilinde yapılan sslahatların da duyurucusu olmuştur. Tarihi birer kaynak olmaları açısından önemli bilgi içeren vilâyet gazeteleri, yayınlandıkları bölgelerle ilgili bilgiler sunmuşlardır. Bu çalışmamızda Tuna Vilâyet Gazetesi’nin ilk 100 nüshası incelenmiştir.

Anahtar Kelimeler: Tuna, Gazete, Rusçuk, Midhat Paşa.

\section{The First Publication Activites and Tuna Newspaper in the Ottoman State}

\section{Abstract}

In 1839 the Ottoman Empire, with the proclamation of Tanzimat Edict, as with all areas made an effort to establish a new central structure in the central and provincial administration.

* Bulgaristan Müslümanları Başmüftülüğg̈ Vakıflar Bölümü Sorumlusu. 
In order to resolve the problems resultant from internal and external political, social and economic developments, on November $7^{\text {th }}, 1864$, prepared in advance with some small changes, "Danube Provinces Regulation" published in "Takvimi Vekayi" and entered into force. The article nine in Regulation is intended to establish one printing house in each province. In this direction the first provincial newspaper was published in the Danube province.

Newspapers published in the provinces during the Ottoman period were the official newspaper of these provinces. The Province newspapers, provided information about both the services of the government to the public and news about the social life. In this context "Tuna Vilayet Gazetesi" (Danube Province Newspaper) had become the voice of the reforms carried out within the province.

Newspapers provinces in terms of being a source of important information including the date, have provided important information about the region they are posted. In this study, the first 100 copies of the newspaper were investigated Danube Vilayet. In view of the fact that the province newspapers contain important historical information, they provided valuable information for the provinces they had published within. This paper examined the first 100 copies of the "Tuna Vilayet Gazetesi”.

Key Words: Danube, Newspaper, Ruse, Midhat Pasha.

\section{Giriş}

Basın, günlük ya da haftalık, olarak, güncel olaylara ilişkin bilgileri içeren yayınların bütünüdür. Genellikle günlük basın ürünlerine gazete, haftalık, onbeş günlük veya aylık yayınlanan basın ürünlerine de dergi denilmektedir. ${ }^{1}$

Fikrî faaliyetler, insanların düşünme yetisine sahip oldukları günden itibaren başlamıştır. Bu faaliyetlerin tekâmülü, merhaleleri, görünüşleri bilimler tarihinin konusudur. Basın ve yayın da, fikrî faaliyetlerin muayyen bir tezahür şekli olarak ilimler tarihinin içine girer ve tekâmül işleviyle, bu bilimin içinde tetkik edilir. ${ }^{2}$

Haberleri ve fikirleri toplama, yayma, diğer değimle başkalarına ulaştırma sanatının, bugün bütün dünyada kullanılan müşterek adı, "Gazetecilik", bu meslek ve sanatın icrasını mümkün kılan müessese de "Basın'dır".

1 M. Nuri İnuğur, Basın ve Yayın Tarihi, İstanbul, 1958, s. 19.

2 Muharrem D. Mercanlıgil, "Basın ve Yayın Tarihi Vesilesiyle", Türk Kütüphaneciliği Dergisi, C. 5, S. 1, Ankara, 1956, s. 53. 
İnsan, çevresinde ve dünyada olup bitenleri öğrenmek ve öğrendiklerini ya da düşündüklerini başkalarına duyurmak ihtiyacını hisseder. Bu ihtiyaç az çok her insanın tabiatında vardır, bu ihtiyacın giderilmesi için girişilen çeşitli teşebbüsler neticesinde bugün basın yayın müessesesi doğmuştur. ${ }^{3}$

\section{Matbaanın Kurulması ve İlk Basım Faaliyetleri}

"Matbaacılık", bir kalıp boya vasıtası ile bir şeklin bir satıh üzerine çok miktarda kopyasının çıkarılması tekniği ve bu tekniğin kitap meydana getirmede kullanılmasidir. ${ }^{4}$

Matbaanın Avrupa'daki öncüsü olan Juhannes Gutenberg, Rhen Nehri kıyısındaki Meins Şehri'nin zengin ve soylu ailelerinden birine mensuptur. 1346 yllında şehirde çıkan bir isyan üzerine, ailesi ile birlikte Strasburg'a göç etmiştir. Babasının ölümünden sonra bir kuyumcu dükkânında çalışmaya başlamış, daha sonra geçimini temin etmek için bir dükkân açmış ve burada tahtalar üzerine oyma yazı yazıp bunları kâğıtlara basarak satmaya başlamıştır. Tahtadan harfler kesip, bunları yan yana getirerek cümleler oluşturmayı ve bunları kâğıda basmayı denemiş ise de, tahtanın dayanıksız olması nedeniyle bu amacını gerçekleştirememiştir. Kelimeleri ve tümceleri tahtaya kazıma yerine her bir harfi tahta ya da maden parçasına kazıyıp, onları yan yana dizerek satır oluşturmanın daha kolay ve ekonomik olduğunu fark etmesi, bugünkü matbaanın da temellerinin atılmasını sağlamıştır. ${ }^{5}$ Bunun üzerine Meins Şehri'ne dönen Gutenberg, Faust adındaki bir zenginle ortak matbaa kurmuştur. ${ }^{6}$

\section{Matbaanın Osmanlı İmparatorluğu'na Girişi ve Gelişmesi}

Osmanlılarda ilk basımevi, Gutenberg' in Avrupa'da 1455'te bastığ 1 ilk kitaptan yaklaşık 40 yıl sonra kurulmuştur. Osmanlı topraklarında ilk basımevini David ve Samuel ismindeki Musevi kardeşler Hz. Musa'ya verilen Torah'1 İstanbul'da 1494 yılında yayınlayarak faaliyete geçirmişlerdir. Bu matbaayı daha sonraki yıllarda Ermeni ve Rum basımevleri takip etmiştir.?

3 H. Refik Ertuğ, Basın ve Yayın Hareketleri Tarihi, İstanbul, 1970, s. 5-6.

4 Hidayet Nuhoğlu, "Müteferrika Matbası ve Bazı Mülahazalar" Osmanlı, Ankara 1999, C. VII, s. 221.

5 Berrin Küçükcan, “Dünden Bugüne Matbaanın Serüveni”, http://eprints.rclis.org/8770/1/ BerrinKucukcan.pdf 30.01.2016/ H: 09:51.

6 M. Nuri İnuğur, a.g.e, s. 50.

7 Ali Gevgilili, “Türkiye Basını”, Cumhuriyet Dönemi Türkiye Ansiklopedisi, İstanbul, 1983, C. I, s. 203. 
Osmanlı Devleti'nin gerileme dönemine girip büyük bunalımlar ile karşılaştığı XVIII. yüzyılda, basımevi kurmak Osmanlı Türkleri için de giderek bir gerekliliğe dönüşmüştür. Özellikle Tanzimat'tan sonra yetişen Osmanlı aydınları Batı'yı bir güç, batılılaşmayı da güçlenme alameti olarak algılamışlardır. Bu gelişmeler doğrultusunda İstanbul'da bir Türk matbaasının kurulması kaçınılmaz hale gelmiştir. İbrahim Müteferrika ile Said Efendi'ye uzun mücadelelerinden sonra, ilk basımevinin kurulması için 1726 yılında dönemin sultanı III. Ahmet tarafından ferman verilmiştir. ${ }^{8}$ Kurucusunun adı ile anılan Müteferrika Matbaası'nda, 1745 yılında İbrahim Müteferrika'nın ölümüne kadar çoğu tarih, coğrafya, gramer ve lügat türünden olmak üzere toplam on yedi kitap basılmıştır. İlk yıllarda matbaalarda bazı siyasi ve ekonomik nedenlerden dolayı tefsir, hadis, fıkıh ve kelâm gibi dinî eserlerin basılmasına izin verilmemiştir. ${ }^{9}$ Müteferrika Matbaası'nda kullanılan harfler yaklaşık olarak günümüzün 18 punto harf büyüklüğüne tekabül etmektedir. Said Mehmet Çelebi ve İbrahim Müteferrika, İstanbul'da Sultan Selim semtinde İbrahim Müteferrika'nın evinde kurdukları ilk matbaayı "Dârü't-Tıbaati'l-Âmire" adı ile faaliyete geçirmişlerdir. Bu matbaada kitaplar için dört ve haritalar için iki baskı makinesi bulundurulmuştur. ${ }^{10}$ Bu matbaayı 1795 'te kurulan Mühendishane Matbaası ile 1802'de kurulan Üsküdar Matbaası takip etmişlerdir. ${ }^{11}$

Matbaacılığın gelişmesine basın ve yayın alanındaki gelişmeler şüphesiz büyük katkıda bulunmuştur. Basının gelişmesi ile birlikte birçok matbaa kurulmuştur. Bununla birlikte özellikle yerel basının faaliyet göstermesi, her vilâyette matbaa kurulması, matbaacılığın yayılmasına ve tanınmasına yardımcı olmuştur.

Osmanlı topraklarında basın ve yayının gelişmesine zemin hazırlamış olan ilk matbaalar arasında "Mühendishane", "Üsküdar", "Dârü't Tıbbati'l-Âmire" matbaalarını zikredebiliriz. ${ }^{12}$ Bu matbaalardan başka Tanzimat'a kadar olan yıllarda Osmanlı matbaacılığında önemli iz bırakan bir diğer matbaa da Kavalalı Mehmet Ali Paşa'nın 1822'de Kahire'de kurdurduğu "Bulak Matbaası'dır". Kullandı̆̆ italik harflerle bastığı divanlarla, Osmanlı insanının sempatisini kazanmış ve basma kitabının yaygınlaşmasına büyük ölçüde vesile olmuştur.

8 Mustafa Akbulut, "İbrahim Müterferrika ve İlk Türk Matbaası", Türkler, Ankara, 2002, C. XIV, s. 922; Server R. İskit, Türkiyede Neşriyat Hareketleri Tarihine Genel Bir Baklş, İstanbul, 1939, s. 5-6.

9 Mustafa Akbulut, a.g.m., s. 922 v.d.

10 Osman Ersoy, Türkiye'ye Matbaanın Girmesi ve İlk Basılan Eserler, Ankara, 1959, s. 35.

11 Abdullah Uçman, “ Tanzimattan Sonra Basın ve Edebiyat”, Osmanlı, Ankara, 1999, C. IX, s. 753.

12 Hidayet Nuhoğlu, "Müteferrika Matbaası ve Bazı Mülahazalar”, Osmanl, Ankara, 1999, C. VII, s. 222. 
II. Mahmut zamanında baskı işlerine de önem verilmiştir. 1831 yılında Üsküdar'da açılan basımevi, padişahın emri ile Bayezit'teki Kaptan Paşa Hamamına nakledilmiş, bu matbaanın bitişiğinde "Takvim-i Vekâyi”i basmak için "Takvimhâne-i Âmire" basımevi kurulmuştur. ${ }^{13}$

\section{Osmanlılarda Basının Gelişmesi}

Osmanlılarda iletişim faaliyetleri modernleşmenin bir vasıtası olarak başlamıştır. 1839 yılında ilan edilen Tanzimat'tan önce merkezi yönetim tarafından verilen resmi bir bildiri, yerel yönetimlere "ulak" veya "tatar" adı verilen görevliler tarafından iletilmiştir. Yerel yönetimler de, merkezden iletilen haberleri "tellallar" ve "imamlar" aracıllı̆̆ ile halka duyurmuşlardır. ${ }^{14}$

Basım sanatının Osmanlı Devleti'ne yabancı olmamasına rağmen ve İbrahim Müteferrika tarafından kitaplar basılıp satılmasına rağmen, devlet genelinde egemen olan aşırı taassup nedeniyle Türkçe gazetelerin yayınlanmaya başlanması yabancı dille yayınlanan gazetelere göre uzun zaman gecikmiştir. İlk gazete de tıpkı kitaplarda olduğu gibi Fransızca olarak "Bulletin de Nouvelles" ismi ile yayınlanmıştır. ${ }^{15}$ Tanzimat dönemi Türk basın tarihi açısından en önemli dönemlerinden birini oluşturmuştur. Çünkü Türkçe süreli yayınların başlangıcı ve esas olarak gelişmeleri bu dönemdedir. ${ }^{16}$

1828 yılında Mısır valisi Kavalalı Mehmet Ali Paşa ilk Türkçe-Arapça “Vekâyi-i Mısriyye” gazetesini çıkarmıştır. ${ }^{17}$ Bâb-1 Âli, 20 Ekim 1827 tarihinde Ruslara karşı Navarin Muharebesi'ni de kaybedince Avrupa'da yalnız kalmıştır. Böyle bir ortamda Sultan II. Mahmut, uzun süredir tasarladığı düşüncesini uygulamaya geçirerek, "Takvim-i Vekâyi”yi yayınlatmıştır. ${ }^{18}$

Islahatçı ve yenilikçi bir padişah olan Sultan II. Mahmut, "Takvim-i Vekâ$y i$ " ile yakından ilgilenmiş ve gazetenin toplumun her kesimi tarafından rahat bir şekilde anlaşılması için sade bir dille yayınlanmasına önem vermiştir. Takvim-i Vekâyi’nin özelliklerinden birisi de, Osmanlı Devleti'nin çok uluslu yapısı

13 Nuri Akbayar “Osmanlı'da Basın”, Tanzimat’tan Cumhuriyete Türkiye Ansiklopedisi, İstanbul, 1985, C. VII, s. 1683.

14 Kemal Kapakl1, "Başlangıçtan Bugüne Urfa Basını”, http://e dergi.marmara.edu.tr/maruid/ article/view/ 50000 13241, 30.01.2016 H: 10:12. s. 244.

15 M. Nuri İnuğur, a.g.e., s. 165; Kemal Kapaklı, a.g.m., s. 244.

16 Nesimi Yazıcı, Tanzimat Dönemi Basını Konusunda Bir Değerlendirme, Ankara, 1994, s. 56.

17 Orhan Kuloğlu, "Osmanlı Basını, İçeriği ve Rejimi”, Tanzimat’tan Cumhuriyete Türkiye Ansiklopedisi, C. I, s. 69.

18 Orhan Kuloğlu, a.g.m., s. 69-70. 
göz önünde bulundurularak, bütün vatandaşların istifade edebilmesi için Türkçe hariç beş dilde yayınlanmış olmasıdır (Fransızca, Arapça, Farsça, Rumca, Ermenice). ${ }^{19}$

"Takvim-i Vekâyi" yayın hayatının ilk dönemlerinde Sultan II. Mahmut'un yakın ilgi ve alâkası sayesinde düzenli bir şekilde yayınlanmışsa da Tanzimat döneminde gazetenin yayınlanmasında aksaklıklar meydana gelmeye başlamıştır. Bütün çabalara rağmen "Takvim-i Vekâyi" arzu edilen düzene kavuşturulamamıştır. Bütün olumsuzluklara rağmen, Osmanlı idarecileri Türkçe ile birlikte bölgede konuşulan dillerde yani iki hatta üç dilde vilâyet gazetelerini neşretmeye başlamışlardır. ${ }^{20}$

\section{Tanzimat'ın İlanı ve İlk Vilayet Gazetesi}

Tanzimat'ın ilânından sonra, mahallî idarelerle ilgili ilk büyük düzenleme Sultan I. Abdülaziz döneminde 7 Kasım1864 tarihinde çıkarılan nizamnâme ile yapılmıştır. Bu nizamnâme eyalet sistemini kaldırarak vilâyet sisteminin temelini oluşturmuştur. ${ }^{21}$

Tanzimat dönemine gelindiğinde vilâyetlerin oluşturulması sürecinde, kültürel alanda yapılan en önemli yenilik, her vilâyette bir matbaanın kurulmasıdır. 7 Kasım 1864 tarihli Vilâyet Nizamnamesi’nin yedinci maddesine göre vilâyet matbaası mektupçunun idaresine verilmiştir. Düzenlemelerden anlaşıldığı üzere vilâyet matbaa ve gazeteleri, resmi bildirileri duyurmakla birlikte, yerel idarenin uygulamalarını da desteklemişlerdir. Vilâyet matbaalarının kurulması, bölge gazeteciliğinin doğmasını sağlarken, yönetenler ile yönetilenler arasında bir bağ oluşturmuşlardır. ${ }^{22} \mathrm{Bu}$ yolda ilk adım atan Midhat Paşa dır. 3 Mart 1865 tarihinde Türkçe ve Bulgarca olarak, ilk başta haftada bir defa yayınlanan "Tuna Gazetesi" yayın hayatına başlamışır. ${ }^{23}$ Gazete muntazam bir şekilde yayın hayatını 1 Haziran 1877 yılına kadar devam etmiştir. ${ }^{24}$

19 Nesimi Yazıcı, Takvim-i Vekâi Belgeler, Ankara, 1983, s. 51.

20 Nesimi Yazıcı, Tanzimat Dönemi Basını Konusunda Bir Değerlendirme, Ankara, 1994 s. 56-57.

21 Mustafa Gençoğlu, “1864 ve 1871 Vilâyet Nizamnamelerine Göre Osmanlı Taşra İdaresinde Yeniden Yapılanma”, Çankırı Karatekin Üniversitesi Sosyal Bilimler Enstitüsü Dergisi, 2 (1) s.29-50.

22 Uygur Kocabaşoğlu, Ali Birinci, "Osmanlı Vilâyet Gazete ve Matbaaları Üzerine Gözlemler” Kebikeç, Say1 2, Ankara, 1995, s. 102-103.

23 Nesimi Yazıc1, a.g.e., s. 72-74.

24 Uygur Kocabaşoğlu, “Tuna Vilayet Gazetesi”, OTAM, Sayı 2, Ankara, 1991, s. 143. 
Bâb-1 Âli, mülkî idarede yenilik yapılmasına karar verdikten sonra örnek vilâyet olarak Tuna Vilâyeti'nin kurulmasını kararlaştırmıştır. Yeni kurulan vilâyetin idaresine, daha önce bu bölgede önemli başarılara imza atmış olan Midhat Paşa tayin olunmuştur. Paşa, Avrupa'ya yaptığı seyahat esnasında, matbaa ve basının önemini iyice idrak etmiştir. Bu konu hakkında "Tuna Gazetesi" şu yazıyı yazmıştır: "Bir halkın ve bir memleketin emniyet ve mamuriyeti ve saadet-i hâli içün ibtida en lâzım ve vacip olan tedbir izâle-i cehalet ve hüsn-i terbiyet kazlyyeleri olub bunun husûlü dâi bir taraftan esbâbının ta'mîim ve tahsîli ve hüsni terbiyesi içün ahlâk ve adât-ı haseneyi icâb iden usûl ve kavâidin te'sis ve neşri ile vücuda geldiğinden ve asrımızda fenn-i tabaat bu misillû teshilâtın vasita-i müstekıllesi ve umûmen vakûf ve mâlumâtın adetâ bir makinesi olduğundan vilâyet-i cedîdenin te'sis buyrulan usûl ve nizâmât-ı adîdesinin âsâr-ı nâfiasina ilâveten merkez$i$ vilâyette bir matbaanin dahi vaz' ve ihdasiyle neşr-i ulûm ve fünûnun tehsil-i vesaili hususunda şâyân-ı musâde-i seniyye-i hazret-i padişah-i dahi memleketve ahalinin matlub ve mültezem-i âlî olan saadet ve mamuriyeti levazımında olmasıyla derhal iktizası icra olunarak Türkçe ve Bulgarca lisanlarında matbuât-ı resmiyye ve edebiyye mahsus olmak üzere nefis Rusçuk'ta açılan matba-i vilâyet mezhebçe ve devletçe muzîr olmayan her dürlü kütüb ve risâilin tab'ına me'zun olduğu gibi......" 25

Tuna Vilâyeti Nizamnamesi'nin dokuzuncu maddesi gereğince bir vilâyet matbaasının kurulması gerekmektedir. ${ }^{26}$ Midhat Paşa vilâyet matbaasını faaliyete geçirerek sultana methiyeler ve övgüler içeren eserler basmak ve vilâyette icra edilen 1slahatları halka duyurmayı amaçlamıştır. ${ }^{27}$

Tuna Vilâyet Matbaası, hurufat, makine, taşbasma, mücellithane ve depo olmak üzere beş bölüme ayrılmıştır. Matbaada iki adet büyük harf makinesi ile bir adet harf basma makinesi kullanılmıştır. Matbaa, Türkçe, eski ve yeni Slavca, Fransızca ve Rumca baskı yapmaya olanak verecek oldukça zengin harf çeşidine sahiptir. Bu harfler Bulgarca, Fransızca, Rumca ve Türkçe dillerinde kullanılmak üzere temin edilmişlerdir. ${ }^{28}$ Ayrıca matbaada zarf, defter ve benzeri kırtasiye malzemelerini imal etmek için dört adet makine hizmet vermiştir. ${ }^{29}$

25 Tuna Gazetesi, Say1 1, 16 Şevval 1281.

26 Hüdai Şentürk, Osmanlı Devletinde Bulgar Meselesi, Türk Tarih Kurumu Yayınları, Ankara, 1992, s. 254

27 Georgi Pletnuov, Midhat Paşa i Upravlenieto na Bılgarskiya Vilâyet, Veliko Tırnovo, 1994, s. 81.

28 Uygur Kocabaşoğlu, a.g.m., s. 144.

29 İsmail Eren "Tuna Vilâyet Matbaası ve Neşriyatı”, Türk Kültürü, C. III, Ankara, 19641965, s. 313. 
"Tuna Gazetesi”, Tuna Vilâyet Matbaası'nda basılmıştır. Bu nedenle gazetede çalışanlar ile matbaada çalışanların kadrosunu tam olarak ayırmak mümkün değildir. Kadro şu görevlilerden oluşmaktadır: Matbaa müdürü, muhasebeci ve muavini, mücellit ustası ve üç çırağı, makineci ve iki yardımcısı, gazete başyazarı ve muavini, Türkçe başmürettip ve üç yardımcısı, Bulgarca başmürettip ve dört yardımcısı, iki Bulgarca ve bir Fransızca tercüman, biri genel ve diğeri Rusçuk Şehri içinde olmak üzere iki gazete dağtıcısı ile muhtelif yerlerde çalışan on beş maaşlı hademe. ${ }^{30}$ Ayrıca Rusçuk sslâhhanesi talebelerinden on kadar Türk ve Bulgar öğrenci her gün öğlenden sonra matbaada mürettiplik ve mücellitlik zanaat1nı öğrenmişlerdir. Bu öğrenciler arasında başarılı olan bir iki öğrenci Avrupa'ya ihtisas için gönderilip orada öğrendikleri yenilikleri döndüklerinde buralarda da tatbik etmeye çalışmışlardır. ${ }^{31}$

Tuna Vilâyet Matbaası'nda çalışanlar arasında dönemin önemli isimlerini görmek mümkündür. Nitekim bu isimlerden biri Dragan Tsankov'dur ki kendisi aynı zamanda matbaanın ilk müdürüdür. İvan Çorapçiev, başta kendi eserleri olmak üzere birkaç eseri de tercüme ederek yayınlamıştır. Yusuf Ziya Efendi, matbaa litografyacısı ve daha sonraki yıllarda matbaa müdürüdür. Matbaada çalışanlar arasında en enteresan sima tanınmış yazar ve gazeteci Ahmed Midhat Efendi' dir. ${ }^{32}$

Her yıl gelişme kaydeden ilk Tuna Vilâyet Matbaası, ancak 1877 yılı Haziran ayına kadar hayatta kalabilmiştir. Vuku bulan Rus-Türk savaşı sırasında atılan top mermileri sonucu matbaada büyük çapta maddi hasar meydana gelmiştir. Matbaada kullanılan aletlerin 93 Harbi sonunda sağlam kalan bazı parçaları 1881 yılında Sofya'da kurulan Devlet Matbaası'na nakledilmiştir. Böylece ilk vilâyet matbaası varlığını kısmen de olsa bir başka kuruluşta devam ettirmiştir. ${ }^{33}$

"Tuna Gazetesi", vilâyet gazeteciliği ekseninde yayın hayatına 16 Şevval 1281/3 Mart 1865 tarihinde başlamıştır. Gazete, Tuna Vilâyet Matbaası'nda neşrolunmuştur. Bu konu hakkında Bâb-1 Âli tarafından şu yazı yazılmıştır:

"Atufetlu efendim hazretleri"

Tuna Vilâyet-i celîlesinin nizamname-i mukarreri hükmünce, merkez-i vilâyette ihdas ve ittihaz olunan matbaa, Türkçe ve Bulgarca hurufatını câmî olarak, vilâyetin teshil-i usûl muamelât-ı tahririyesi için vaz' olunduğu gibi hüsn-i terbiye-i umumiyenin ve sabit ve esbabr cümlesinden olmak ve memâlik-i muh-

30 İsmail Selimoğlu, "Balkanlardaki Türk Kültürünün Dünü Bugünü Yarını”, Uluslararası Seтроzуӥти (26-28 Ekim 2001), Bildiri Kitabl, Bursa, 2002, s. 135.

31 İsmail Eren, a.g.m., 313-314.

32 İsmail Eren, a.g.m., s. 315.

33 İsmail Eren, a.g.m., s. 315. 
telifeden Bulgaristan'a gelen gazetelerden halkça bir nevi istiğna hâsıl edilmek üzere nısfı Türkçe ve nısfi Bulgarca bir gazete tab-ı dahi tasavvurat-ı vâkıa iktizasindan bulunduğuna binaen şimdilik numûne ve bunun külliyatına mukaddime olarak bu defa tertib ve tab' olunmuş olan ilk nüshası gönderildiğine dair vilâyet-i müssarun ileyhâ valisi devletlü Midhat Paşa hazretlerinin varit olan tahrirat zikrolunan gazete ile beraber arz ve takdim kılındı siyak-ı iş'ardan anlaşıldı $\breve{g} l$ vechiyle Bulgaristan'ın hiçbir mahallinde matbaa olmadiğından saye-i muvaffakiyet-vaye-i hazret-i şehinşahide şimdi böyle bir gazetenin ihdasl ve bir bendinde ilân olunduğu üzere kâffe-i kütüp ve resailinin bu matbaada sair yerlerden daha ehven fiyatla yapılacă̆ının vadedilmesi memnuniyet-i umumiyetle istilzam eylemiş olmasıla muvafik-ı emr-ü ferman-ı hazret-i padişahi buyurulduğu halde takdir-i icraatını mutazammın vali-i müşarun ileyhe cevapnâme tasdir olunacă̆ beyaniyle tezkere-i senaverî terkîm olundu efendim" 9 Şevval 1281

Mâruz-l çaker-i kemineleridir ki bende-i dest-i tevkir olan işbu tezkire-i samiye-i asafaneleriyle zikrolunan tahrirat ve gazete manzur-ı mealî-meftûr-ı hazret-i padişahî buyurulmuş ve ber mûcib-i isti'lzân müşarun ileyhe cevapnâme tasdir olunmasina müteallik ve şeref südûr buyurulan emr-ü irade-i seniyye-i cenabımülükâne icab-ı âisinden olarak mezkûr tahrirat ve gazete yine savb-i sami-i asafanelerine iade kllınmısolmakla olbabda emr-ü ferman hazret-i veliyyü'l-emrindir. 10 Şevval $1281^{34}$

Tuna Vilâyet Gazetesi'nin muntazam bir şekilde yayınlanmasında, o dönemin valisinin yanında, gazetede yazar olarak görev yapan Ahmed Midhat Efendi'nin de üstün gayretlerini dikkate almak gerekmektedir. ${ }^{35}$

Tuna Vilâyet Gazetesi yayın hayatına başladı̆̆ında haftada bir gün çıkmıştır. Bu durum gazetede: "iş bu gazete dâhiliye ve hariciye ve her türlü mebâhis-i şâmil olarak haftada bir defa Çarşamba günleri çıkar" . ${ }^{36}$ Ancak Tuna Gazetesi'nin H.1282 yılı 1 Mart ayı (55. nüshasından) itibaren: "iş bu gazete dâhiliye ve hariciye ve her türlü mebâhis-i şâmil olarak haftada iki defa Çarşamba ve Pazar günleri çıkar" ${ }^{37}$ Gazetenin yayınlanacağı tarih bayram günlerine tesadüf ederse, gazetenin o sayısının yayınlanmayacağı bir önceki sayısında okuyucularına duyurulmuştur. ${ }^{38} \mathrm{Bu}$ tarihten itibaren gazetenin haftada iki defa yayınladığı, gazetenin üst kısmındaki tarih ve numaralarından da belli olmaktadır. Vilâyet dâhilinde ya-

34 Bekir Sitkı Baykal, Midhat Paşa, Siyasi ve İdari Şahsiyeti, T.C. Ziraat Bankası 100. Yıl Armağan1, 1964, Kıral Matbaası, s. 10-11.

35 İsmail Eren, a.g.m., s. 315.

36 Tuna Gazetesi, Sayı 1, 16 Şevval 1281.

37 Tuna Gazetesi, Say1 55, 5 Zilkade 1282.

38 Tuna Gazetesi, Say1 64, 7 Zilhicce 1282. 
şayan müşteriler gibi, vilâyet haricinde ikamet eden kimselerin de posta ücretini ödeyerek gazeteyi alabilecekleri bildirilmiştir. ${ }^{39}$

“Tuna Vilâyet Gazetesi'nin” daha ilk sayılarından itibaren tirajında artış görülmeye başlamıştır. Bu konu ile ilgili gazete şu açıklamayı yapmıştır: "Işs bu gazetenin mrekez-i vilâyette bidâyet-i vaz' ve ihdasında ne mikdar nüsha çıkarllacağı bittab'î malum olmıyarak yalnız birinciden üçüncü ve dördüncü numroya kadar dörder beşeryüz nüsha basılıp neşr olunmuş olması üzerine fevka'l-me'mûl zuhur iden müsteriler birinci nüshasindan itibaren gazeteye talip olmuş iseler de birinci numrodan dörde kadar nüshalar berminvâl-i mukarrer az basılmış ve onlar dahi meccanen dă̆gttılmış olmasıyla mevcudu kalmadığından bunların yeniden tabıyla müşterilere irsali lâzım gelup...."

Her süreli yayın gibi Tuna Gazetesi'nin teknik bilgileri hakkında bazı malumatlar vermek istiyoruz. Tuna Gazetesi'nin sayfaları hakkında şunlar söylenebilir: Gazete yayın hayatına başladığı dönemden itibaren iki sayfa Türkçe ve iki sayfa Bulgarca olarak yayınlanmıştır. Bununla birlikte gazetede her hicri ayın sonunda ilave ekler yayınlanmış ve bu ilavelerde yalnız emir, kanun, tüzük ve muhakeme kararları yer almıştır. ${ }^{41}$ Tuna Gazetesi ilk sayısından sekizinci sayısına kadar olan nüshalarında, her sayfası üç sütundan oluşmuştur. 14 Zilhicce/ 28 Nisan 1865 tarihli dokuzuncu sayısından itibaren her sayfası dört sütundan ibaret olarak yayın hayatına devam etmiştir.

“Tuna Vilâyet Gazetesi’nin” ebadı hakkında kısaca şu bilgileri verebiliriz: Gazetenin birinci sayısından sekizinci sayısına kadar olan nüshalarının boyutları $37 \times 26$ cm'dir. 14 Zilhicce 1281/ 28 Nisan 1865 tarihli dokuzuncu sayıdan itibaren gazetenin sayfa boyutları $54 \times 36 \mathrm{~cm}$ dir.

“Tuna Gazetesi’nin” sayfa düzeni anlayışı kesinlikle günümüzdeki gazeteler gibi değildir, fakat basıldığı dönemin şartlarına göre mükemmel olduğu söylenebilir. Bu dönem gazetelerinde manşet anlayışı söz konusu değildir, yalnız bölüm başlıkları vardır. Tuna Gazetesi'nin birinci sayfasında, en üstte ortada büyük harflerle yazılmış "Tuna" ismi vardır. Başlığın sol tarafında gazetenin numarası ve malî tarih (bazı sayılarda malî tarih verilmemiştir) bulunmaktadır. Sağ tarafta hicrî tarih ile gazetenin yayınlandığı gün yazılıdır. Bu bilgilerin alt kısmında iki sıra halinde, abonelik şartları, senelik fiyatı, altı aylık fiyatı ve her nüshasının fiyatı hakkında bilgiler yer almaktadır. Bu ifadenin altında da: "Dahili vilâyetten mâadâ mahallen içün bu fiyata posta ücreti zam olunur, seneliği veyahut altı ay-

39 Tuna Gazetesi, Say1 52, 20 Şevval 1282.

40 Tuna Gazetesi, Sayı 12, 6 Muharrem 1282.

41 İsmail Eren, a.g.m., s. 316. 
lı̆̆ı almak istenildiği halde merkez vilâyet matbaasına müraacat olunmak lâzım gelür" ifadesi yer almaktadır.

Tuna başlığı altında sağdan sola iki çizgi vardır, bu çizgilerin arasında, "Işs $b u$ gazete dâhiliye ve hariciye ve her türlü mebahisi şamil olarak haftada bir defa Çarşamba günleri çıkar” yazısı bulunmaktadır. Ancak 55. sayıdan itibaren " haftada iki defa Çarşamba ve Pazar günleri çıkar” yazısı yer almaktadır. Gazetenin Osmanlıca kısmında bu bilgiler yer alırken, Bulgarca kısmında fark vardır. Gazetenin sağ üst köşesinde sayı numarası bulunmakta, sol üst köşesinde basıldığ 1 yıl, bu bilgilerin ortasında da gazetenin yayınlandığı gün bilgileri yer almaktadır. Bu bilgilerin alt kısmında şerit altında iki çizgi vardır, çizgilerin arasında orta kısımda gazetenin ismi yazılı, ismin bulunduğu hizada sağ köşede gazetenin yıllık, altı aylık ve her nüshasına dair bilgiler yer almaktadır, sol tarafında ise gazetenin haftada kaç defa çıktığı ve abonelik şartları yazılıdır. Başlı̆̆ın altında büyük yazılarla "İç ve dış haberleri içeren ve her türlü düşünceye yer veren gazetedir" ibaresi yer almaktadır.

Gazetenin ikinci sayfasında, sayfa numarası, tarih ve başlık yoktur. Ancak Bulgarca kısmının sağ üst köşesinde sayfa numarası, üstte ortada gazetenin ismi, alt orta kısmında ise basıldı $\breve{~} 1$ şehir ve matbaa hakkında kısa bilgiler yer almaktadır. Gazete sayfalarında yukarıdan aşă̆ıya çizilmiş çizgiler sütün aralarını ayırmaktadır. Bu yönü ile gazetede boyuna sayfa düzeni usulü kullanılmıştır.

"Tuna Gazetesi'nde" yer alan haberler belli başlıklar altında okuyucuya sunulmuştur. Gazetenin ilk sekiz sayısında haberler üç ana başlık altında verilmiştir. Bu başlıklar: "Mevâdd-ı Hususiye", "Havadis-i Hariciye" ve "ilânat". Sekizinci sayısından itibaren haberler dört ana başlık altında verilmeye başlanmıştır. "Mevâdd-ı Hususiye", "Mevâdd-ı Umumiye", " Havadis-i Hariciye" ve "Illânat".

- "Mevâdd-ı Hususiye" başlığı altındaki haberler tamamen vilâyetle ilgili haberlerdir, bu haberler daima ilk sayfada yer almışlardır.

- "Mevâdd-ı Umumiye” başlığı altındaki haberler, Osmanlı ülkesiyle ilgili her alandaki haberleri içermektedir.

- "Havadis-i Hariciye” başlı̆̆ altındaki haberler, yabancı ülke ve şahıslarla ilgili haberlerdir ki, bu haberler İstanbul gazetelerinden alıntı yapılarak yayınlanmıştır.

- "Ilânât” bölümü ikiye ayrılabilir:

a) Kamusal ilânlar

b) Özel ilânlar

Gazete, yayın hayatına başladığında, her nüshasının fiyatı 40 para, seneliği 40 ve altı aylığı 25 kuruştur. Ancak vilâyet haricinden gazeteyi almak isteyenler, ga- 
zetenin fiyatı hariç posta ücretini de ödemeleri icap etmiştir. 1282 yılı Mart ayından itibaren gazetenin 55. nüshasında, gazetenin fiyatında artış olmuştur. Seneliği 70, altı aylığı 40 kuruşa ve her nüshası da 40 paradan satılmıştır.

\section{Sonuç}

Yeni vilayet nizamnamesinin uygulanmaya başladığı 1864 yılında faaliyete başlayan Tuna Vilayet Matbaası, gazete dışında da hizmet vermiştir.

Tuna Vilayet Gazetesi, Tanzimat Dönemi'nin önemli bir basın organı ve ilk vilâyet gazetesidir. Bu özelliği ile Tuna Gazetesi'nin, taşra basınına öncülük, önderlik ve rehberlik yaptığı söylenebilir. Gazete, vilâyetin sosyo-ekonomik, dinî ve kültürel yönlerden ilerlemesini amaçlayan ve yönetenlerle yönetilenler arasında bağ oluşturmuştur. Dolayısıyla Tuna Gazetesi kendi dönemine has özellikleri olan ve o dönemdeki mevcut gereksinimleri satırlara dökerek sonraki nesillere sunan değerli belgeler bütünüdür. Gazetenin, oldukça sade bir üslup benimsemesi, Türkçenin gelişmesine ve yaygınlaşmasına önemli katkıda bulunmuştur. Gazete, sadece Müslüman Türk okuyucuları açısından değil, Bulgar okuyucuları açısından da aynı sadelik yöntemini izlemiştir.

\section{Kaynakça}

Akbayar, Nuri, "Osmanlıda Basın”, Tanzimattan Cumhuriyete Türkiye Ansiklopedisi, C. VII, İstanbul, 1985.

Akbulut, Mustafa, “İbrahim Müteferrika ve İlk Türk Matbaası”, Türkler, C. XIV, Ankara, 2002.

Baykal, Bekir Sıtkı, Midhat Paşa, Siyasi ve İdari Şahsiyeti, T.C. Ziraat Bankası 100. Yıl Armağanı, 1964, Kıral Matbaası.

Eren, İsmail, “Tuna Vilâyet Matbaası ve Neşriyatı”, Türk Kültürü, C. III, Ankara, 1964-1965.

Ersoy, Osman, Türkiye’ye Matbaanın Girmesi ve İlk Basılan Eserler, Ankara, 1959.

Ertuğ, H. Refik, Basın ve Yayın Hareketleri Tarihi, İstanbul, 1970.

Gençoğlu, Mustafa, “1864 ve 1871 Vilâyet Nizamnamelerine Göre Osmanlı Taşra İdaresinde Yeniden Yapılanma”, Çankırı Karatekin Üniversitesi Sosyal Bilimler Enstitüsü Dergisi, $2(1)$.

Gevgilili, Ali, “Türkiye Basını”, Cumhuriyet Dönemi Türkiye Ansiklopedisi, C. I, İstanbul, 1983.

İğnur, M. Nuri, Basın ve Yayın Tarihi, İstanbul, 1958.

İskit, Server R., Türkiyede Neşriyat Hareketleri Tarihine Genel Bir Baklş, İstanbul, 1939.

Kapaklı, Kemal, "Başlangıçtan Bugüne Urfa Basını”, http://e dergi.marmara.edu.tr/maruid/ article/view/5000013241

Kocabaşoğlu, Uygur, “Tuna Vilayet Gazetesi”, OTAM, Sayı 2, Ankara, 1991. 
Kocabaşoğlu, Uygur, Birinci, Ali, “Osmanlı Vilâyet Gazete ve Matbaaları Üzerşne Gözlemler”, Kebikeç, Sayı 2, Ankara, 1995.

Koloğlu, Orhan, “ Osmanlı Basım, İçeriği ve Rejimi”,Tanzimattan Cumhuriyete Türkiye Ansiklopedisi, C. I, İstanbul, 1985.

Küçükcan, Berrin, “Dünden Bugüne Matbaanın Serüveni”, http://eprints.rclis.org/8770/1/ Berrin Kucukcan.pdf 30.01.2016/

Mercanlıgil, Muharrem D., "Basın ve Yayın Tarihi Vesilesiyle”, Türk Kütüphaneciliği Dergisi, C. 5, Sayı. 1, Ankara, 1956.

Nuhoğlu, Hidayet, "Müteferrika Matbaası ve Bazı Mülahazalar", Osmanl, C. VII, Ankara, 1999.

Pletnyov, Georgi, Midhat Paşa i Upravlenieto na Bılgarskiya Vilâyet, Veliko Tırnovo, 1994.

Selimoğlu, İsmail, "Balkanlardaki Türk Kültürünün Dünü Bugünü Yarını", Uluslararası Semроzуӥти (26-28 Ekim 2001), Bildiri Kitabı, Bursa, 2002.

Şentürk, Hüdai, Osmanlı Devletinde Bulgar Meselesi, Türk Tarih Kurumu Yayınları, Ankara, 1992.

Tuna Gazetesi, Sayı 1, 16 Şevval 1281.

Tuna Gazetesi, Sayı 12, 6 Muharrem 1282.

Tuna Gazetesi, Sayı 52, 20 Şevval 1282.

Tuna Gazetesi, Say1 55, 5 Zilkade 1282.

Tuna Gazetesi, Sayı 64, 7 Zilhicce 1282.

Uçman, Abdullah, "Tanzimat'tan Sonra Basın ve Edebiyat", Osmanlı, C. IX, Ankara 1999.

Yazıcı, Nesimi, Takvim'i Vekâi Belgeler, Ankara 1983.

Yazıcı, Nesimi, Tanzimat Dönemi Basını Konusunda Bir Değerlendirme, Ankara 1994. 